\title{
SRC wt Allele
}

National Cancer Institute

\section{Source}

National Cancer Institute. SRC wt Allele. NCI Thesaurus. Code C51124.

Human SRC wild-type allele is located within 20q12-q13 and is approximately $61 \mathrm{~kb}$ in length. This allele, which encodes proto-oncogene tyrosine-protein kinase Src protein, plays a role in signal transduction pathways involved in the inhibition of endothelial cell apoptosis, regulation of the actin cytoskeleton, and the production of gonadotropins in pituitary cells. An allelic variant of the SRC gene, which produces a truncated, inactive protein, is associated with the development and metastasis of both breast and colon cancer. 